\title{
Formation mechanisms of atmospheric nitrate and sulfate during the winter haze pollution periods in Beijing: gas-phase, heterogeneous and aqueous-phase chemistry
}

\author{
Pengfei Liu ${ }^{1,2,3,5}$, Can Ye ${ }^{1,3}$, Chaoyang Xue ${ }^{1,3}$, Chenglong Zhang ${ }^{1,2,3}$, Yujing Mu ${ }^{1,2,3,4}$, and Xu Sun ${ }^{1,6}$ \\ ${ }^{1}$ Research Center for Eco-Environmental Sciences, Chinese Academy of Sciences, Beijing, 100085, China \\ ${ }^{2}$ Center for Excellence in Urban Atmospheric Environment, Institute of Urban Environment, \\ Chinese Academy of Sciences, Xiamen, 361021, China \\ ${ }^{3}$ University of Chinese Academy of Sciences, Beijing, 100049, China \\ ${ }^{4}$ National Engineering Laboratory for VOCs Pollution Control Material \& Technology, \\ University of Chinese Academy of Sciences, Beijing, 100049, China \\ ${ }^{5}$ Key Laboratory of Atmospheric Chemistry, China Meteorological Administration, Beijing, 100081, China \\ ${ }^{6}$ Beijing Urban Ecosystem Research Station, Beijing, 100085, China
}

Correspondence: Yujing Mu (yjmu@rcees.ac.cn)

Received: 29 October 2019 - Discussion started: 13 November 2019

Revised: 6 March 2020 - Accepted: 9 March 2020 - Published: 7 April 2020

\begin{abstract}
A vast area in China is currently going through severe haze episodes with drastically elevated concentrations of $\mathrm{PM}_{2.5}$ in winter. Nitrate and sulfate are the main constituents of $\mathrm{PM}_{2.5}$, but their formations via $\mathrm{NO}_{2}$ and $\mathrm{SO}_{2}$ oxidation are still not comprehensively understood, especially under different pollution or atmospheric relative humidity $(\mathrm{RH})$ conditions. To elucidate formation pathways of nitrate and sulfate in different polluted cases, hourly samples of $\mathrm{PM}_{2.5}$ were collected continuously in Beijing during the wintertime of 2016 . Three serious pollution cases were identified reasonably during the sampling period, and the secondary formations of nitrate and sulfate were found to make a dominant contribution to atmospheric $\mathrm{PM}_{2.5}$ under the relatively high $\mathrm{RH}$ condition. The significant correlation between $\mathrm{NOR}, \mathrm{NOR}=\mathrm{NO}_{3}^{-} /\left(\mathrm{NO}_{3}^{-}+\mathrm{NO}_{2}\right)$, and $\left[\mathrm{NO}_{2}\right]^{2} \times\left[\mathrm{O}_{3}\right]$ during the nighttime under the $\mathrm{RH} \geq 60 \%$ condition indicated that the heterogeneous hydrolysis of $\mathrm{N}_{2} \mathrm{O}_{5}$ involving aerosol liquid water was responsible for the nocturnal formation of nitrate at the extremely high $\mathrm{RH}$ levels. The more often coincident trend of NOR and $[\mathrm{HONO}] \times[\mathrm{DR}]($ direct radiation $) \times\left[\mathrm{NO}_{2}\right]$ compared to its occurrence with [Dust $] \times\left[\mathrm{NO}_{2}\right]$ during the daytime under the $30 \%<\mathrm{RH}<60 \%$ condition provided convincing evidence that the gas-phase reaction of $\mathrm{NO}_{2}$ with $\mathrm{OH}$ played
\end{abstract}

a pivotal role in the diurnal formation of nitrate at moderate $\mathrm{RH}$ levels. The extremely high mean values of SOR, $\mathrm{SOR}=\mathrm{SO}_{4}^{2-} /\left(\mathrm{SO}_{4}^{2-}+\mathrm{SO}_{2}\right)$, during the whole day under the $\mathrm{RH} \geq 60 \%$ condition could be ascribed to the evident contribution of $\mathrm{SO}_{2}$ aqueous-phase oxidation to the formation of sulfate during the severe pollution episodes. Based on the parameters measured in this study and the known sulfate production rate calculation method, the oxidation pathway of $\mathrm{H}_{2} \mathrm{O}_{2}$ rather than $\mathrm{NO}_{2}$ was found to contribute greatly to the aqueous-phase formation of sulfate.

\section{Introduction}

In recent years, severe haze has occurred frequently in Beijing as well as the North China Plain (NCP) during the wintertime, which has aroused great attention from the public due to its adverse impact on atmospheric visibility, air quality and human health (Chan and Yao, 2008; Zhang et al., 2012, 2015).

To mitigate the severe haze pollution situations, a series of regulatory measures for primary pollution sources have been implemented by the Chinese government. For example, coal combustion for heating in winter has gradually been replaced 
with electricity and natural gas in the NCP, coal-fired power plants have been strictly required to install flue-gas denitration and desulfurization systems (Chen et al., 2014), stricter control measures such as terminating production in industries and construction as well as the odd and even number rule for vehicles have been performed in megacities during the period of the red alert for haze. These actions have had tremendous effects on reducing pollution levels of primary pollutants including $\mathrm{PM}_{2.5}$ (fine particulate matter with an aerodynamic diameter of less than $2.5 \mu \mathrm{m}$ ) in recent years (Li et al., 2019). However, serious pollution events still occurred in many areas of Beijing-Tianjin-Hebei (BTH) region in December 2016 and January 2017 (Li et al., 2019). It has been acknowledged that the severe haze pollution is mainly ascribed to stagnant meteorological conditions with high atmospheric relative humidity (RH) and low mixed boundary layer height, strong emissions of primary gaseous pollutants, and rapid formation of secondary inorganic aerosols (SIAs, the sum of sulfate, nitrate and ammonium), especially sulfate and nitrate (Cheng et al., 2016; Guo et al., 2014; Huang et al., 2014). Some studies suggested that the contribution of SIAs to $\mathrm{PM}_{2.5}$ was higher than $50 \%$ during the most serious haze days (Quan et al., 2014; Xu et al., 2017; Zheng et al., 2015a).

Generally, atmospheric sulfate and nitrate are formed through the oxidations of the precursor gases $\left(\mathrm{SO}_{2}\right.$ and $\left.\mathrm{NO}_{2}\right)$ by oxidants (e.g., $\mathrm{OH}$ radicals, $\mathrm{O}_{3}$ ) via gas-phase, heterogeneous and aqueous-phase reactions (Ravishankara, 1997; Wang et al., 2013; Yang et al., 2015). It should be noted that a recent study proposed remarkable emissions of primary sulfate from residential coal combustion with the sulfur content of coal in the range of $0.81 \%-1.88 \%$ in Xi' an (Dai et al., 2019), but the primary emissions of sulfate can be neglected due to the extremely low sulfur content of coal $(0.26 \%-$ $0.34 \%$ ) used prevailingly in the NCP (Du et al., 2016; Li et al., 2016). Atmospheric RH is a key factor that facilitates SIA formation and aggravates the haze pollution (Wu et al., 2019), and hence the secondary formations of sulfate and nitrate are simply considered to be mainly via gas-phase reactions at relatively low atmospheric $\mathrm{RH}$ levels $(\mathrm{RH}<30 \%)$ and heterogeneous reactions and aqueous-phase reactions at relatively high atmospheric $\mathrm{RH}$ levels $(\mathrm{RH}>60 \%$ ) (Li et al., 2017). However, their formation mechanisms at different atmospheric RH levels still remain controversial and unclear (Cheng et al., 2016; Ge et al., 2017; Guo et al., 2017; Li et al., 2018; M. Liu et al., 2017; Wang et al., 2016; Yang et al., 2017). For example, recent studies proposed that atmospheric $\mathrm{SO}_{2}$ oxidation by $\mathrm{NO}_{2}$ dissolved in aqueous aerosol phases under the extremely high atmospheric RH conditions played a dominant role in sulfate formation under almostneutral aerosol solutions (a pH range of 5.4-7.0) during the serious pollution periods (Cheng et al., 2016; Wang et al., 2018, 2016). However, M. Liu et al. (2017) and Guo et al. (2017) found that the aerosol $\mathrm{pH}$ estimated by the ISORROPIA II model was moderately acidic (a pH range of 3.04.9), and thus the pathway of $\mathrm{SO}_{2}$ aqueous-phase oxida- tion by dissolved $\mathrm{NO}_{2}$ was unimportant during severe haze events in China. Additionally, although the pathway of $\mathrm{N}_{2} \mathrm{O}_{5}$ heterogeneous hydrolysis has been recognized as being responsible for the nocturnal formation of $\mathrm{NO}_{3}^{-}$under relatively high atmospheric RH conditions (Tham et al., 2018; Wang et al., 2018a, b), the effects of $\mathrm{NO}_{2}$ gas-phase chemistry and $\mathrm{NO}_{2}$ heterogeneous chemistry on the diurnal formation of $\mathrm{NO}_{3}^{-}$under moderate atmospheric $\mathrm{RH}$ conditions $(30 \%<\mathrm{RH}<60 \%)$ have not yet been understood. Therefore, measurements of the species in $\mathrm{PM}_{2.5}$ in different polluted cases during the wintertime are urgently needed to elucidate formation pathways of sulfate and nitrate.

In this study, hourly filter samples of $\mathrm{PM}_{2.5}$ were collected continuously in Beijing during the wintertime of 2016, and the pollution characteristics and formation mechanisms of sulfate and nitrate in the $\mathrm{PM}_{2.5}$ samples were investigated comprehensively under different atmospheric $\mathrm{RH}$ conditions in relation to gas-phase, heterogeneous and aqueous-phase chemistry.

\section{Materials and methods}

\subsection{Sampling and analysis}

The sampling site was chosen on the rooftop (around $25 \mathrm{~m}$ above the ground) of a six-story building at Research Center for Eco-Environmental Sciences, Chinese Academy of Sciences (RCEES, CAS), which is located in the northwest of Beijing and has been described in detail by our previous studies (P. Liu et al., 2016, 2017). The location of the sampling site $\left(40^{\circ} 00^{\prime} 29.85^{\prime \prime} \mathrm{N}, 116^{\circ} 20^{\prime} 29.71^{\prime \prime} \mathrm{E}\right)$ is presented in Fig. S1 in the Supplement. Hourly $\mathrm{PM}_{2.5}$ samples were collected on prebaked quartz fiber filters $(90 \mathrm{~mm}$, Munktell) from 7 to 23 January 2016 by median-volume samplers (Laoying-2030) with a flow rate of $100 \mathrm{~L} \mathrm{~min}^{-1}$. Watersoluble ions (WSIs), including $\mathrm{Na}^{+}, \mathrm{NH}_{4}^{+}, \mathrm{Mg}^{2+}, \mathrm{Ca}^{2+}, \mathrm{K}^{+}$, $\mathrm{Cl}^{-}, \mathrm{NO}_{2}^{-}, \mathrm{NO}_{3}^{-}$and $\mathrm{SO}_{4}^{2-}$, as well as carbon components including organic carbon (OC) and element carbon (EC) in the filter samples, were analyzed by ion chromatography (Wayeal IC6200) and a thermal optical carbon analyzer (DRI Model 2001A), respectively (P. Liu et al., 2017). Analysis relevant for quality assurance \& quality control (QA/QC) was presented in detail in Sect. S1 of the Supplement. Atmospheric $\mathrm{H}_{2} \mathrm{O}_{2}$ and HONO were monitored by an AL2021$\mathrm{H}_{2} \mathrm{O}_{2}$ monitor (Aero-Laser GmbH, Germany) and a set of double-wall glass stripping coil samplers coupled with ion chromatography (SC-IC), respectively (Ye et al., 2018; Xue et al., 2019a, b). More details about the measurements of $\mathrm{H}_{2} \mathrm{O}_{2}$ and HONO are described in Sect. S2. Meteorological data, including wind speed, wind direction, ambient temperature and $\mathrm{RH}$, as well as air quality index (AQI) derived from $\mathrm{PM}_{2.5}, \mathrm{SO}_{2}, \mathrm{NO}_{x}, \mathrm{CO}$ and $\mathrm{O}_{3}$, were obtained from Beijing urban ecosystem research station in RCEES, CAS (http://www.bjurban.rcees.cas.cn/, last access: 6 June 2019). 


\subsection{Aerosol liquid water content and $\mathrm{pH}$ prediction by the ISORROPIA II model}

The ISORROPIA II model was employed to calculate the equilibrium composition for the $\mathrm{Na}^{+}-\mathrm{K}^{+}-\mathrm{Ca}^{2+}-$ $\mathrm{Mg}^{2+}-\mathrm{NH}_{4}^{+}-\mathrm{Cl}^{-}-\mathrm{NO}_{3}^{-}-\mathrm{SO}_{4}^{2-}-\mathrm{H}_{2} \mathrm{O}$ aerosol system, which is widely used in regional and global atmospheric models and has been successfully applied in numerous studies for predicting the physical state and composition of atmospheric inorganic aerosols (Fountoukis and Nenes, 2007; Guo et al., 2015; Shi et al., 2017). It can be used in two modes: forward mode and reverse mode. Forward mode calculates the equilibrium partitioning given the total concentrations of gas and aerosol species, whereas reverse mode involves predicting the thermodynamic compositions based only on the concentrations of aerosol components. Forward mode was adopted in this study because reverse mode calculations have been verified to be not suitable to characterize aerosol acidity (Guo et al., 2015; Hennigan et al., 2015; Murphy et al., 2017; Pathak et al., 2004; Weber et al., 2016). The ISORROPIA II model is available in "metastable" or "solid + liquid" state solutions. Considering the relatively high RH during the sampling period, the metastable state solution was selected in this study due to its better performance than the latter (Bougiatioti et al., 2016; Guo et al., 2015; M. Liu et al., 2017; Weber et al., 2016). Additionally, although the gaseous $\mathrm{HNO}_{3}, \mathrm{H}_{2} \mathrm{SO}_{4}$ $\mathrm{HCl}$ and $\mathrm{NH}_{3}$ were not measured in this study, gas-phase input with the exception of $\mathrm{NH}_{3}$ has an insignificant impact on the aerosol liquid water content (ALWC) and $\mathrm{pH}$ calculation due to the lower concentrations of $\mathrm{HNO}_{3}, \mathrm{H}_{2} \mathrm{SO}_{4}$ and $\mathrm{HCl}$ as compared with $\mathrm{NH}_{3}$ in the atmosphere (Ding et al., 2019; Guo et al., 2017). Based on the long-term measurement in the winter in Beijing, an empirical equation between $\mathrm{NO}_{x}$ and $\mathrm{NH}_{3}$ concentrations was derived from the previous study (Meng et al., 2011), that is, $\mathrm{NH}_{3}$ (in parts per billion $)=0.34 \times \mathrm{NO}_{x}$ (in parts per billion $)+0.63$, which was employed for estimating the $\mathrm{NH}_{3}$ concentration in this study. The predicted daily average concentrations of $\mathrm{NH}_{3}$ varied from 3.3 to $36.9 \mu \mathrm{g} \mathrm{m}^{-3}$, with a mean value of 16.6 and a median value of $14.6 \mu \mathrm{g} \mathrm{m}^{-3}$, which were in line with those (7.6-38.1, 18.2 and $16.2 \mu \mathrm{g} \mathrm{m}^{-3}$ for the daily average concentrations, the mean value and the median value of $\mathrm{NH}_{3}$, respectively) during the winter of 2013 in Beijing in the previous study (Zhao et al., 2016).

Then, the aerosol $\mathrm{pH}$ can be calculated by the following equation:

$\mathrm{pH}=-\log _{10} \frac{1000 \times H^{+}}{W}$,

where $H^{+}$(in micrograms per cubic meter) and $W$ (in micrograms per cubic meter) are the equilibrium particle hydrogen ion concentration and aerosol water content, respectively, both of which can be output from ISORROPIA II.

\subsection{Production of sulfate in aqueous-phase reactions}

The previous studies showed that there were six pathways from the aqueous-phase oxidation of $\mathrm{SO}_{2}$ to the production of sulfate, i.e., $\mathrm{H}_{2} \mathrm{O}_{2}$ oxidation, $\mathrm{O}_{3}$ oxidation, $\mathrm{NO}_{2}$ oxidation, transition metal ions (TMIs) $+\mathrm{O}_{2}$ oxidation, methyl hydrogen peroxide (MHP) oxidation and peroxyacetic acid (PAA) oxidation (Cheng et al., 2016; Zheng et al., 2015a). Because some TMIs, such as Ti(III), V(III), Cr(III), Co(II), $\mathrm{Ni}(\mathrm{II}), \mathrm{Cu}(\mathrm{II})$ and $\mathrm{Zn}$ (II), displayed much less catalytic activity (Cheng et al., 2016), only Fe(III) and Mn(II) were considered in this study. In addition, due to the extremely low concentrations of MHP and PAA in the atmosphere, their contributions to the production of sulfate can be ignored (Zheng et al., 2015a). To investigate the formation mechanism of sulfate during the serious pollution episodes, the contributions of $\mathrm{O}_{3}, \mathrm{H}_{2} \mathrm{O}_{2}, \mathrm{NO}_{2}$ and $\mathrm{Fe}(\mathrm{III})+\mathrm{Mn}$ (II) to the production of sulfate in aqueous-phase reactions were calculated by formulas as follows (Cheng et al., 2016; Ibusuki and Takeuchi, 1987; Seinfeld and Pandis, 2006):

$$
\begin{aligned}
& -\left(\frac{\mathrm{d}[\mathrm{S}(\mathrm{IV})]}{\mathrm{d} t}\right)_{\mathrm{O}_{3}}=\left(k_{0}\left[\mathrm{SO}_{2} \mathrm{H}_{2} \mathrm{O}\right]+k_{1}\left[\mathrm{HSO}_{3}^{-}\right]\right. \\
& \left.+k_{2}\left[\mathrm{SO}_{3}^{2-}\right]\right)\left[\mathrm{O}_{3(\mathrm{aq})}\right] \\
& -\left(\frac{\mathrm{d}[\mathrm{S}(\mathrm{IV})]}{\mathrm{d} t}\right)_{\mathrm{H}_{2} \mathrm{O}_{2}}=\frac{k_{3}\left[\mathrm{H}^{+}\right]\left[\mathrm{HSO}_{3}^{-}\right]\left[\mathrm{H}_{2} \mathrm{O}_{2(\mathrm{aq})}\right]}{1+K\left[\mathrm{H}^{+}\right]} \\
& -\left(\frac{\mathrm{d}[\mathrm{S}(\mathrm{IV})]}{\mathrm{d} t}\right)_{\mathrm{Fe}(\mathrm{III})+\mathrm{Mn}(\mathrm{II})}=k_{4}\left[\mathrm{H}^{+}\right]^{a}[\mathrm{Mn}(\mathrm{II})] \\
& -\left(\frac{\mathrm{d}[\mathrm{S}(\mathrm{IV})]}{\mathrm{d} t}\right)_{\mathrm{NO}_{2}}=k_{5}\left[\mathrm{NO}_{2(\mathrm{aq})}\right][\mathrm{S}(\mathrm{III})][\mathrm{S}(\mathrm{IV})]
\end{aligned}
$$

where $k_{0}=2.4 \times 10^{4} \mathrm{M}^{-1} \mathrm{~s}^{-1}, k_{1}=3.7 \times 10^{5} \mathrm{M}^{-1} \mathrm{~s}^{-1}, k_{2}=$ $1.5 \times 10^{9} \mathrm{M}^{-1} \mathrm{~s}^{-1}, k_{3}=7.45 \times 10^{7} \mathrm{M}^{-1} \mathrm{~s}^{-1}, K=13 \mathrm{M}^{-1}$, $k_{4}=3.72 \times 10^{7} \mathrm{M}^{-1} \mathrm{~s}^{-1}$, and $a=-0.74$ (for $\mathrm{pH} \leq 4.2$ ) or $k_{4}=2.51 \times 10^{13} \mathrm{M}^{-1} \mathrm{~s}^{-1}$, and $a=0.67$ (for $\mathrm{pH}>4.2$ ) and $k_{5}=(1.24-1.67) \times 10^{7} \mathrm{M}^{-1} \mathrm{~s}^{-1}$ (for $5.3 \leq \mathrm{pH} \leq 8.7$; the linear interpolated values were used for $\mathrm{pH}$ between 5.3 and 8.7 ) at $298 \mathrm{~K}$ (Clifton et al., 1988); [O $\left.\mathrm{O}_{3(\mathrm{aq})}\right],\left[\mathrm{H}_{2} \mathrm{O}_{2(\mathrm{aq})}\right]$ and $\left[\mathrm{NO}_{2(\mathrm{aq})}\right]$ can be calculated by the Henry's constants, which are $1.1 \times 10^{-2}, 1.0 \times 10^{5}$ and $1.0 \times 10^{-2} \mathrm{M} \mathrm{atm}^{-1}$ at $298 \mathrm{~K}$ for $\mathrm{O}_{3}, \mathrm{H}_{2} \mathrm{O}_{2}$ and $\mathrm{NO}_{2}$ respectively (Seinfeld and Pandis, 2006). As for [Fe(III)] and [Mn(II)], their concentrations entirely depended on the values of $\mathrm{pH}$ due to the precipitation equilibriums of $\mathrm{Fe}(\mathrm{OH})_{3}$ and $\mathrm{Mn}(\mathrm{OH})_{2}$ (Graedel and Weschler, 1981). Considering the aqueous-phase ionization equilibrium of $\mathrm{SO}_{2}$, the Henry's constants of $\mathrm{HSO}_{3}^{-}, \mathrm{SO}_{3}^{2-}$ and $\mathrm{S}(\mathrm{IV})$ can be expressed by the equations as follows (Seinfeld and Pandis, 2006): 
$H_{\mathrm{HSO}_{3}^{-}}^{*}=H_{\mathrm{SO}_{2}} \frac{K_{\mathrm{S} 1}}{\left[\mathrm{H}^{+}\right]}$

$H_{\mathrm{SO}_{3}^{2-}}^{*}=H_{\mathrm{SO}_{2}} \frac{K_{\mathrm{S} 1} K_{\mathrm{S} 2}}{\left[\mathrm{H}^{+}\right]^{2}}$

$H_{\mathrm{S}(\mathrm{IV})}^{*}=H_{\mathrm{SO}_{2}}\left(1+\frac{K_{\mathrm{S} 1}}{\left[\mathrm{H}^{+}\right]}+\frac{K_{\mathrm{S} 1} K_{\mathrm{S} 2}}{\left[\mathrm{H}^{+}\right]^{2}}\right)$,

where $H_{\mathrm{SO}_{2}}=1.23 \mathrm{M} \mathrm{atm}^{-1}, \quad K_{\mathrm{S} 1}=1.3 \times 10^{-2} \mathrm{M} \quad$ and $K_{\mathrm{S} 2}=6.6 \times 10^{-8} \mathrm{M}$ at $298 \mathrm{~K}$. In addition, all of the rate constants $(k)$, Henry's constants $(H)$ and ionization constants $(K)$ are evidently influenced by the ambient temperature and are calibrated by formulas as follows (Seinfeld and Pandis, 2006):

$$
\begin{aligned}
& k(T)=k\left(T_{0}\right) e^{\left[-\frac{E}{R}\left(\frac{1}{T}-\frac{1}{T_{0}}\right)\right]} \\
& H(T)=H\left(T_{0}\right) e^{\left[-\frac{\Delta H}{R}\left(\frac{1}{T}-\frac{1}{T_{0}}\right)\right]} \\
& K(T)=K\left(T_{0}\right) e^{\left[-\frac{E}{R}\left(\frac{1}{T}-\frac{1}{T_{0}}\right)\right]},
\end{aligned}
$$

where $T$ is the ambient temperature, $T_{0}=298 \mathrm{~K}$; both $E / R$ and $\Delta H / R$ varied in the different equations, and their values can be found in Cheng et al. (2016).

Furthermore, mass transport was also considered for multiphase reactions in different medium and across the interface in Sect. S3.

\section{Results and discussion}

\subsection{Variation characteristics of the species in $\mathbf{P M}_{2.5}$ and typical gaseous pollutants}

The concentrations of the species in $\mathrm{PM}_{2.5}$ and typical gaseous pollutants including $\mathrm{NO}_{2}, \mathrm{SO}_{2}, \mathrm{O}_{3}, \mathrm{HONO}$ and $\mathrm{H}_{2} \mathrm{O}_{2}$ as well as atmospheric $\mathrm{RH}$ are shown in Fig. 1. The meteorological parameters - wind speed, wind direction, ambient temperature and direct radiation (DR) - and the concentrations of $\mathrm{PM}_{2.5}$ are displayed in Fig. S2. During the sampling period, the concentrations of the species in $\mathrm{PM}_{2.5}$ and typical gaseous pollutants varied similarly on a timescale of hours with a distinct periodic cycle of 3-4d, suggesting that meteorological conditions played a vital role in accumulation and dispersion of atmospheric pollutants (Xu et al., 2011; Zheng et al., 2015b). For example, the relatively high levels of $\mathrm{PM}_{2.5}\left(>100 \mu \mathrm{g} \mathrm{m}^{-3}\right.$ ) usually occurred under the relatively stable meteorological conditions with the low south wind speed $\left(<2 \mathrm{~m} \mathrm{~s}^{-1}\right)$ and high RH $(>60 \%)$, which favored the accumulation of pollutants. Besides meteorological conditions, the extremely high concentrations of the species in $\mathrm{PM}_{2.5}$ might be mainly ascribed to strong emissions of primary pollutants and rapid formation of secondary aerosols during the wintertime in Beijing.
The average concentrations of the species in $\mathrm{PM}_{2.5}$ and typical gaseous pollutants during clean or slightly polluted (C\&SP) episodes $\left(\mathrm{PM}_{2.5}<75 \mu \mathrm{g} \mathrm{m}^{-3}\right.$ ), during polluted or heavily polluted (P\&HP) episodes $\left(\mathrm{PM}_{2.5} \geq 75 \mu \mathrm{g} \mathrm{m}^{-3}\right.$ ), and during the whole sampling period are illustrated in Table 1. It is evident that the average concentrations of $\mathrm{NO}_{3}^{-}, \mathrm{SO}_{4}^{2-}$, $\mathrm{NH}_{4}^{+}$, OC and EC during P\&HP episodes were about 5.0, 4.1, 6.1, 3.6 and 3.2 times greater than those during C\&SP episodes, respectively, indicating that the formations of SIAs were more efficient compared to other species in $\mathrm{PM}_{2.5}$ during the serious pollution episodes. Given that the average concentrations of gaseous precursors $\left(\mathrm{NO}_{2}\right.$ and $\left.\mathrm{SO}_{2}\right)$ during P\&HP episodes were approximately a factor of 2.0 2.2 greater than those during $\mathrm{C} \& \mathrm{SP}$ episodes, the obviously higher elevation of $\mathrm{NO}_{3}^{-}$and $\mathrm{SO}_{4}^{2-}$ implied that the oxidations of $\mathrm{NO}_{2}$ and $\mathrm{SO}_{2}$ by the major atmospheric oxidizing agents ( $\mathrm{OH}$ radicals, $\mathrm{O}_{3}, \mathrm{H}_{2} \mathrm{O}_{2}$, etc.) might be greatly accelerated due to the relatively high concentrations of oxidants and atmospheric $\mathrm{RH}$ during the serious pollution episodes (Fig. 1). The average concentration of $\mathrm{H}_{2} \mathrm{O}_{2}$ was found to be a factor of 1.7 greater during P\&HP episodes than during $\mathrm{C} \& S P$ episodes, indicating that atmospheric $\mathrm{H}_{2} \mathrm{O}_{2}$ might contribute to the formation of SIAs, especially sulfate during the serious pollution episodes with high atmospheric $\mathrm{RH}$, which will be discussed in Sect. 3.3.2. However, an obvious decrease in the $\mathrm{O}_{3}$ average concentration was observed during P\&HP episodes compared to C\&SP episodes, which was mainly attributed to the relatively weak solar radiation and the titration of NO during the serious pollution episodes (Ye et al., 2018). In addition, the evidently higher average concentration of HONO during P\&HP episodes compared with C\&SP episodes might be also due to the relatively weak solar radiation as well as the heterogeneous reaction of $\mathrm{NO}_{2}$ on particle surfaces during the serious pollution episodes (Tong et al., 2016; Wang et al., 2017).

\subsection{Three serious pollution cases during the sampling period}

Based on the transition from the clean to polluted periods, three haze cases were identified during the sampling period (Figs. 1 and S2 in the Supplement): from 13:00 UTC+8 on 8 January to $01: 00$ on 11 January (Case 1), from 14:00 on 14 January to 07:00 on 17 January (Case 2) and from 08:00 on 19 January to $02: 00$ on 22 January (Case 3 ). The serious pollution duration in the three cases can last $1-3 \mathrm{~d}$ due to the differences in their formation mechanisms.

In Case 1, the variation trends in the concentrations of the species in $\mathrm{PM}_{2.5}, \mathrm{NO}_{2}, \mathrm{SO}_{2}, \mathrm{HONO}$ and $\mathrm{H}_{2} \mathrm{O}_{2}$ were almost identical and exhibited three pollution peaks at night (Fig. 1), which might be ascribed to the possibility that the decrease in nocturnal mixed boundary layer accelerated the pollutant accumulation (Bei et al., 2017; Zhong et al., 2019). Considering the relatively low RH (15\%-40\%) and wind speeds $\left(<2 \mathrm{~m} \mathrm{~s}^{-1}\right)$ in Case 1 (Fig. S2), primary emissions around 


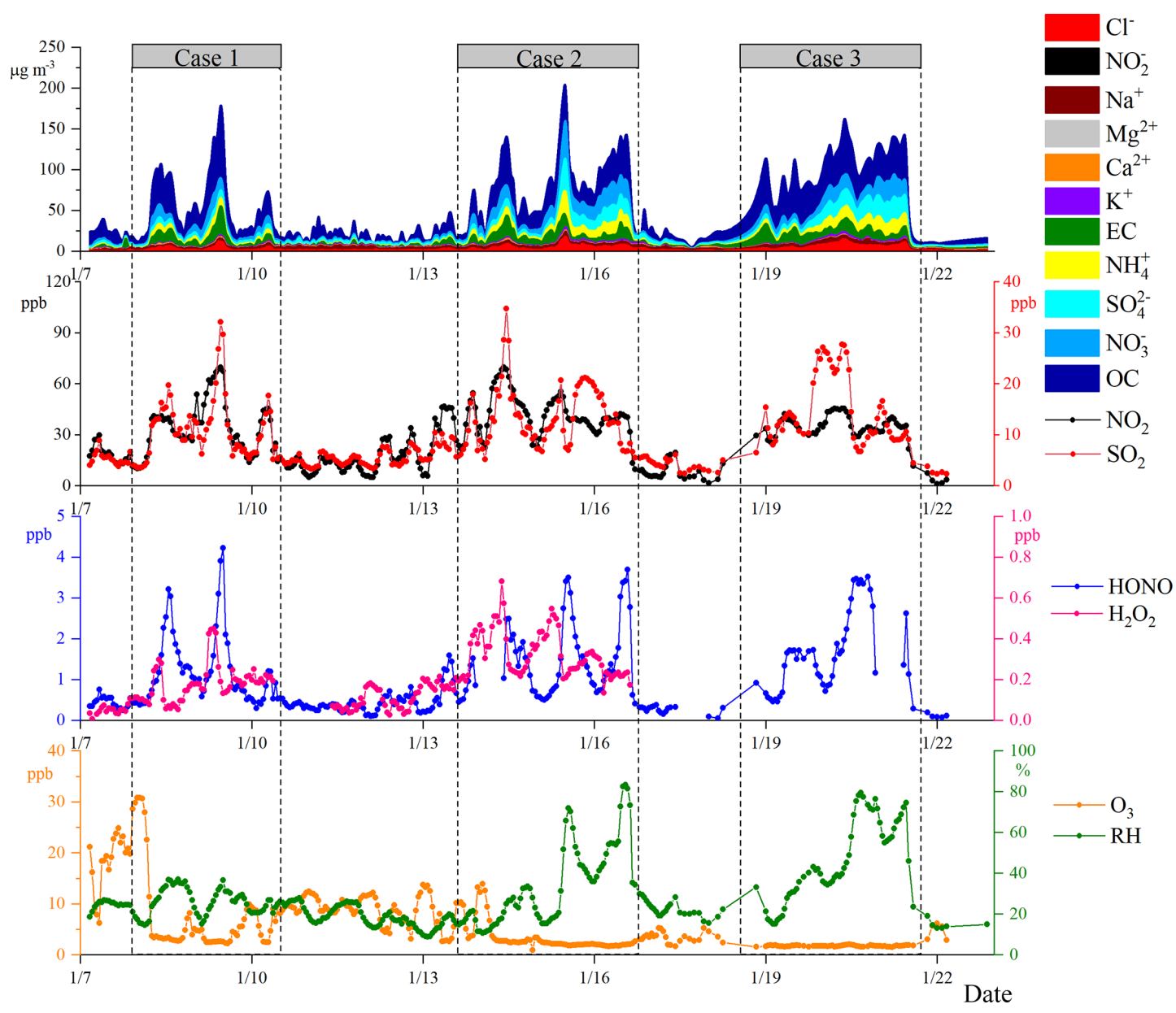

Figure 1. Time series of the species in $\mathrm{PM}_{2.5}$ and typical gaseous pollutants $\left(\mathrm{NO}_{2}, \mathrm{SO}_{2}, \mathrm{O}_{3}, \mathrm{HONO}\right.$ and $\left.\mathrm{H}_{2} \mathrm{O}_{2}\right)$ as well as atmospheric $\mathrm{RH}$ during the sampling period.

the sampling site were suspected to be a dominant source for the increase in the $\mathrm{PM}_{2.5}$ concentrations. Further evidence is that the correlation between the concentrations of $\mathrm{PM}_{2.5}$ and CO is better in Case $1\left(R^{2}=0.55\right)$ than in Case 2 and Case 3 $\left(R^{2}=0.20-0.52\right)$ (Fig. S3). Identical to Case 1 , three obvious pollution peaks were also observed in Case 2 (Fig. 1). The variation trends in the concentrations of the species in $\mathrm{PM}_{2.5}$ and typical gaseous pollutants at the first peak in Case 2 were found to be similar to those in Case 1, which were mainly attributed to their similar formation mechanism. However, the evident decreases in $\mathrm{NO}_{2}$ and $\mathrm{SO}_{2}$ were observed when the concentrations of the species in $\mathrm{PM}_{2.5}$ were increasing, and the atmospheric oxidation pollutant (e.g., $\mathrm{H}_{2} \mathrm{O}_{2}$ ) concentration peaks were prior to others in the last two peaks in Case 2, suggesting that secondary formation from gaseous precursors might be dominant for $\mathrm{PM}_{2.5}$ pollution. The relatively high RH (50\%-80\%) and the low south wind speeds $\left(<2 \mathrm{~m} \mathrm{~s}^{-1}\right)$ in Case 2 (Fig. S2) provided further evidence for the above speculation. In contrast to Case 1 and Case 2, the relatively high south wind speeds $\left(>3 \mathrm{~m} \mathrm{~s}^{-1}\right.$ ) (Fig. S2) with the concentrations of the species in $\mathrm{PM}_{2.5}$ and typical gaseous pollutants increasing slowly (Fig. 1) at the beginning of Case 3 indicated that regional transportation might be responsible for the atmospheric species. Subsequently, the concentrations of the species in $\mathrm{PM}_{2.5}$ remained relatively high when the atmospheric RH continued to be more than $60 \%$, implying that secondary formation from gaseous precursors dominated $\mathrm{PM}_{2.5}$ pollution during the late period of Case 3 .

The average mass proportions of the species in $\mathrm{PM}_{2.5}$ in the three cases are illustrated in Fig. S4; the proportions of the primary species including EC $(10 \%-13 \%), \mathrm{Cl}^{-}(6 \%-$ $7 \%)$ and $\mathrm{Na}^{+}(4 \%)$ in the three cases were almost identical, indicating that primary particle emissions were relatively stable during the sampling period. However, the proportions of SIAs in Case $2(42 \%)$ and Case $3(38 \%)$ were conspicuously greater than that in Case $1(28 \%)$, further confirming that secondary formation of inorganic ions (e.g., nitrate, sulfate) made a significant contribution to atmospheric $\mathrm{PM}_{2.5}$ in Case 2 and Case 3. 
Table 1. The average concentrations of the species in $\mathrm{PM}_{2.5}$ (in micrograms per cubic meter) and typical gaseous pollutants (in parts per billion) during $\mathrm{C} \& \mathrm{SP}$ episodes $\left(\mathrm{PM}_{2.5}<75 \mu \mathrm{g} \mathrm{m}^{-3}\right)$, during P\&HP episodes $\left(\mathrm{PM}_{2.5} \geq 75 \mu \mathrm{g} \mathrm{m}^{-3}\right)$ and during the whole sampling period.

\begin{tabular}{lrrr}
\hline Species & $\begin{array}{r}\text { During C\&SP } \\
\text { episodes }(n=210)\end{array}$ & $\begin{array}{r}\text { During P\&HP } \\
\text { episodes }(n=108)\end{array}$ & $\begin{array}{r}\text { Total } \\
(n=318)\end{array}$ \\
\hline $\mathrm{PM}_{2.5}$ & $30.00 \pm 17.79$ & $113.35 \pm 28.10$ & $58.31 \pm 45.15$ \\
$\mathrm{Na}^{+}$ & $2.88 \pm 1.11$ & $3.68 \pm 1.19$ & $3.15 \pm 1.21$ \\
$\mathrm{Mg}^{2+}$ & $0.05 \pm 0.03$ & $0.08 \pm 0.06$ & $0.06 \pm 0.04$ \\
$\mathrm{Ca}^{2+}$ & $0.52 \pm 0.33$ & $0.67 \pm 0.48$ & $0.58 \pm 0.40$ \\
$\mathrm{~K}^{+}$ & $0.81 \pm 0.42$ & $1.84 \pm 0.73$ & $1.16 \pm 0.73$ \\
$\mathrm{NH}_{4}^{+}$ & $1.90 \pm 1.90$ & $11.52 \pm 4.93$ & $5.17 \pm 5.62$ \\
$\mathrm{SO}_{4}^{2-}$ & $3.64 \pm 1.87$ & $14.96 \pm 7.80$ & $7.47 \pm 7.18$ \\
$\mathrm{NO}_{3}^{-}$ & $3.44 \pm 3.57$ & $17.15 \pm 7.36$ & $8.10 \pm 8.32$ \\
$\mathrm{Cl}^{-}$ & $1.89 \pm 1.20$ & $7.35 \pm 2.97$ & $3.73 \pm 3.26$ \\
$\mathrm{NO}_{2}^{-}$ & $0.06 \pm 0.08$ & $0.06 \pm 0.05$ & $0.06 \pm 0.07$ \\
$\mathrm{OC}^{-}$ & $12.10 \pm 9.25$ & $43.34 \pm 13.88$ & $22.73 \pm 18.48$ \\
$\mathrm{EC}$ & $3.98 \pm 3.42$ & $12.69 \pm 6.43$ & $7.58 \pm 6.51$ \\
$\mathrm{NO}_{x}$ & $39.38 \pm 35.25$ & $107.71 \pm 58.44$ & $62.59 \pm 54.98$ \\
$\mathrm{NO}_{2}$ & $21.46 \pm 13.04$ & $42.81 \pm 10.96$ & $28.71 \pm 15.98$ \\
$\mathrm{SO}_{2}$ & $6.99 \pm 3.64$ & $15.70 \pm 6.55$ & $9.95 \pm 6.35$ \\
$\mathrm{O}_{3}$ & $8.01 \pm 6.35$ & $2.13 \pm 0.56$ & $6.01 \pm 5.87$ \\
$\mathrm{HONO}$ & $0.60 \pm 0.43$ & $1.90 \pm 0.97$ & $1.01 \pm 0.87$ \\
$\mathrm{H}_{2} \mathrm{O}_{2}$ & $0.17 \pm 0.11$ & $0.29 \pm 0.14$ & $0.20 \pm 0.13$ \\
\hline
\end{tabular}

\subsection{Formation mechanism of nitrate and sulfate during serious pollution episodes}

As for nitrate and sulfate in the three cases, the highest mass proportion (18\%) of nitrate was observed in Case 2, whereas the highest mass proportion $(15 \%)$ of sulfate was found in Case 3 (Fig. S4). Although the concentrations of $\mathrm{SO}_{2}$ were obviously lower than the concentrations of $\mathrm{NO}_{2}$ in both Case 2 and Case 3 (Fig. 1 and Table 1), the extremely high proportion of sulfate in Case 3 might be ascribed to the longlasting plateau of RH (Fig. 1) because the aqueous-phase reaction could accelerate the conversion of $\mathrm{SO}_{2}$ to $\mathrm{SO}_{4}^{2-}$. To further investigate the pollution characteristics of nitrate and sulfate during the serious pollution episodes, the relations between NOR $\left(\mathrm{NOR}=\mathrm{NO}_{3}^{-} /\left(\mathrm{NO}_{3}^{-}+\mathrm{NO}_{2}\right)\right)$ as well as SOR $\left(\mathrm{SOR}=\mathrm{SO}_{4}^{2-} /\left(\mathrm{SO}_{4}^{2-}+\mathrm{SO}_{2}\right)\right)$ and $\mathrm{RH}$ are shown in Fig. 2. There were obvious differences in the variations in NOR and SOR under different atmospheric RH conditions. The variation trends in NOR and SOR almost stayed the same when atmospheric RH was below $30 \%$ and then simultaneously increased with atmospheric RH in the range of $30 \%-60 \%$. The enhanced gas-phase reaction and the heterogeneous reaction involving aerosol liquid water might make a remarkable contribution to the elevation of NOR and SOR, respectively, which are further discussed in the following section. Subsequently, the variation trend in NOR slowly decreased, whereas the variation trend in SOR significantly increased when atmospheric RH was above $60 \%$, which was very similar to the previous studies (Sun et al., 2013; Zheng et al.,

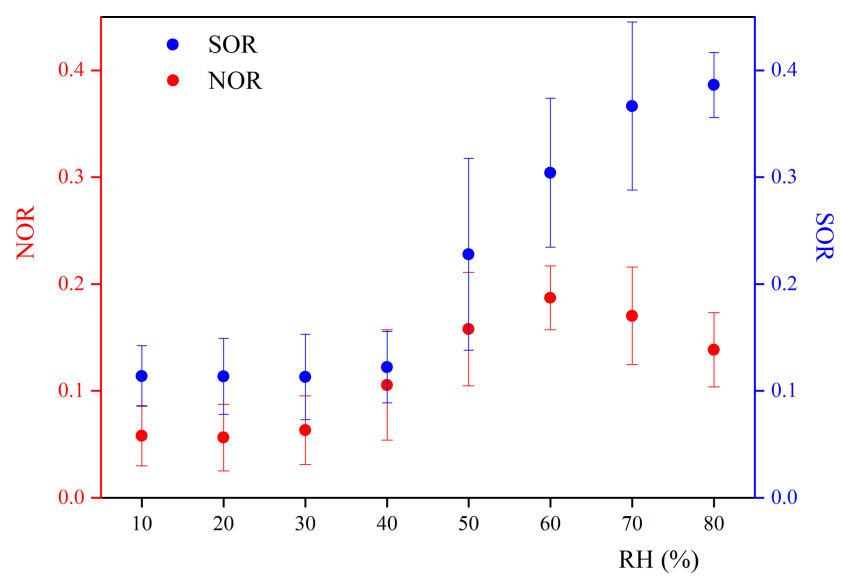

Figure 2. The relations between NOR, SOR and RH during the sampling period.

2015b). Considering that the heterogeneous reactions of $\mathrm{NO}_{2}$ on particle surfaces were dependent on atmospheric RH due to the competition of water for surface reactive sites of particles (Ponczek et al., 2019), the slow reduction in NOR might be due to the suppressed heterogeneous reaction of $\mathrm{NO}_{2}$ to nitrate formation under high-RH conditions (Tang et al., 2017), while the elevation of SOR revealed the dominant contribution of the aqueous-phase reaction to sulfate formation.

\subsubsection{Formation mechanism of nitrate}

Atmospheric nitrate is considered to be mainly from $\mathrm{NO}_{2} \mathrm{ox}-$ idation by $\mathrm{OH}$ radicals in the gas phase, heterogeneous uptake of $\mathrm{NO}_{2}$ on the surface of particles, and heterogeneous hydrolysis of $\mathrm{N}_{2} \mathrm{O}_{5}$ on wet aerosols or chloride-containing aerosols (He et al., 2014, 2018; Nie et al., 2014; Ravishankara, 1997; Wang et al., 2018a). Atmospheric $\mathrm{N}_{2} \mathrm{O}_{5}$ is usually produced by the reaction of $\mathrm{NO}_{3}$ radicals with $\mathrm{NO}_{2}$. Since both $\mathrm{NO}_{3}$ radicals and $\mathrm{N}_{2} \mathrm{O}_{5}$ are easily photolytic during the daytime, the heterogeneous hydrolysis of $\mathrm{N}_{2} \mathrm{O}_{5}$ is a nighttime pathway for the formation of atmospheric nitrate (He et al., 2018; Wang et al., 2018a). As shown in Fig. 3a, the mean values of NOR during the nighttime elevated remarkably with the increase in atmospheric $\mathrm{RH}$; the disproportionation of $\mathrm{NO}_{2}$ and the heterogeneous hydrolysis of $\mathrm{N}_{2} \mathrm{O}_{5}$ involving aerosol liquid water were suspected to dominate the nocturnal formation of nitrate under highRH conditions during the sampling period (Ma et al., 2017; Wang et al., 2018a; Li et al., 2018). However, the production of HONO and nitrate should be equal through the disproportionation of $\mathrm{NO}_{2}$ (Ma et al., 2017), which could not explain the wide gaps between the average concentrations of HONO (about $6.5 \mu \mathrm{g} \mathrm{m}^{-3}$ ) and nitrate (about $20.1 \mu \mathrm{g} \mathrm{m}^{-3}$ ) observed in the nighttime under high-RH conditions during the sampling period. Thus, the disproportionation of $\mathrm{NO}_{2}$ made an insignificant contribution to the nocturnal forma- 
tion of nitrate under high-RH conditions. Considering that atmospheric $\mathrm{NO}_{3}$ radicals are mainly generated via the oxidation of $\mathrm{NO}_{2}$ by $\mathrm{O}_{3}$, the relatively high $\mathrm{O}_{3}$ and $\mathrm{NO}_{2}$ levels could be in favor of the formation of $\mathrm{N}_{2} \mathrm{O}_{5}$ during the nighttime (He et al., 2018; Wang et al., 2018a), and hence the correlation between $\left[\mathrm{NO}_{2}\right]^{2} \times\left[\mathrm{O}_{3}\right]$ and NOR can represent roughly the contribution of the heterogeneous hydrolysis of $\mathrm{N}_{2} \mathrm{O}_{5}$ to atmospheric nitrate at night. As shown in Fig. 3b, although the variations in $\left[\mathrm{NO}_{2}\right]^{2} \times\left[\mathrm{O}_{3}\right]$ in the nighttime (18:00-07:00 UTC+8) were all positively correlated with NOR under the three different RH conditions, their correlation under the $\mathrm{RH} \geq 60 \%$ condition $\left(R^{2}=0.552\right)$ was significantly stronger than those under the $\mathrm{RH}<60 \%$ condition $\left(R^{2} \leq 0.181\right)$. It has been acknowledged that a correlation between two species means that changes in one species impact the other. The stronger the correlation is, the greater the impact is. Therefore, the significantly stronger correlations between NOR and $\left[\mathrm{NO}_{2}\right]^{2} \times\left[\mathrm{O}_{3}\right]$ under the $\mathrm{RH} \geq 60 \%$ condition compared with the $\mathrm{RH}<60 \%$ condition revealed that the heterogeneous hydrolysis of $\mathrm{N}_{2} \mathrm{O}_{5}$ made a remarkable contribution to atmospheric nitrate in the nighttime under high-RH conditions. Additionally, the obviously lower slope of the correlation between NOR and $\left[\mathrm{NO}_{2}\right]^{2} \times\left[\mathrm{O}_{3}\right]$ under the RH $\geq 60 \%$ condition (slope $=11691$ ) compared with the RH $<60 \%$ condition (slope $\geq 17399$ ) (Fig. 3b) also suggested that the formation of atmospheric nitrate during nighttime under high-RH conditions was more sensitive to the pathway of $\mathrm{N}_{2} \mathrm{O}_{5}$.

However, the obvious increase in the mean values of NOR during the daytime (especially for 10:00-17:00 UTC+8) under the $30 \%<\mathrm{RH}<60 \%$ condition (Fig. 3a) indicated that additional sources rather than the heterogeneous hydrolysis of $\mathrm{N}_{2} \mathrm{O}_{5}$ were responsible for the formation of nitrate. To explore the possible formation mechanisms of nitrate in this case, the daily variations in [Dust] (the sum of $\mathrm{Ca}^{2+}$ and $\left.\mathrm{Mg}^{2+}\right) \times\left[\mathrm{NO}_{2}\right]$ and [HONO] (the main source of $\mathrm{OH}) \times[\mathrm{DR}] \times\left[\mathrm{NO}_{2}\right]$, which can represent roughly the heterogeneous reaction of $\mathrm{NO}_{2}$ on the surface of mineral aerosols and the gas-phase reaction of $\mathrm{NO}_{2}$ with $\mathrm{OH}$, are shown in Fig. $3 \mathrm{c}$ and d, respectively. The mean values of $[\mathrm{HONO}] \times[\mathrm{DR}] \times\left[\mathrm{NO}_{2}\right]$ during the daytime were found to be remarkably greater under the $30 \%<\mathrm{RH}<60 \%$ condition than under the $\mathrm{RH} \leq 30 \%$ condition, whereas the mean values of $[$ Dust $] \times\left[\mathrm{NO}_{2}\right]$ almost stayed the same under the two different RH conditions. Considering the coincident trend of NOR and $[\mathrm{HONO}] \times[\mathrm{DR}] \times\left[\mathrm{NO}_{2}\right]$ during the daytime (10:00-17:00 UTC+8) under the $30 \%<\mathrm{RH}<60 \%$ condition, the gas-phase reaction of $\mathrm{NO}_{2}$ with $\mathrm{OH}$ played a key role in the diurnal formation of nitrate at moderate $\mathrm{RH}$ levels with the haze pollution accumulating. It should be noted that the mean values of $[\mathrm{HONO}] \times[\mathrm{DR}] \times\left[\mathrm{NO}_{2}\right]$ decreased dramatically from 14:00 to 17:00 UTC+8 (Fig. 3d), which was not responsible for the high mean values of NOR at that time (Fig. 3a). However, the slight increase in the mean values of $[$ Dust $] \times\left[\mathrm{NO}_{2}\right]$ after 14:00 UTC +8 was ob- served under the $30 \%<\mathrm{RH}<60 \%$ condition (Fig. 3c), and hence the heterogeneous reaction of $\mathrm{NO}_{2}$ on the surface of mineral aerosols was suspected to contribute to the diurnal formation of nitrate at that time under a moderate RH condition.

\subsubsection{Formation mechanism of sulfate}

Atmospheric sulfate is principally from the $\mathrm{SO}_{2}$ oxidation pathway, including gas-phase reactions with $\mathrm{OH}$ radicals or stabilized Criegee intermediates, heterogeneous-phase reactions on the surface of particles, and aqueous-phase reactions with dissolved $\mathrm{O}_{3}, \mathrm{NO}_{2}, \mathrm{H}_{2} \mathrm{O}_{2}$, and organic peroxides, as well as autoxidation catalyzed by TMI (Cheng et al., 2016; Li et al., 2018; Ravishankara, 1997; Shao et al., 2019; Wang et al., 2016; Xue et al., 2016; Zhang et al., 2018). As shown in Fig. 4, similar to the daily variations in NOR, the mean values of SOR were found to elevate remarkably under the $30 \%<\mathrm{RH}<60 \%$ condition compared to the $\mathrm{RH} \leq 30 \%$ condition, especially during 14:0022:00 UTC +8 , which might be mainly ascribed to the enhanced gas-phase reaction and the heterogeneous reaction of $\mathrm{SO}_{2}$ involving aerosol liquid water under the relatively high-RH condition. The extremely high mean values of SOR during the whole day under the $\mathrm{RH} \geq 60 \%$ condition implied that aqueous oxidation of $\mathrm{SO}_{2}$ dominated the formation of sulfate during the severe pollution episodes, which was in line with previous studies (Zhang et al., 2018; Cheng et al., 2016). A key factor that influenced the aqueous oxidation pathways for sulfate formation has been considered to be the aerosol pH (Guo et al., 2017; M. Liu et al., 2017), varying from 4.5 to 8.5 at different atmospheric $\mathrm{RH}$ and sulfate levels during the sampling period (Fig. 5a) on the basis of the ISORROPIA II model. Considering that the aqueousphase chemistry of sulfate formation usually occurs in severe haze events with relatively high atmospheric $\mathrm{RH}$, the aerosol $\mathrm{pH}$ (4.5-5.3) under the $\mathrm{RH} \geq 60 \%$ condition, which was lower than those (5.4-7.0) in the studies of Wang et al. (2016) and Cheng et al. (2016) but was slightly higher than those (3.0-4.9) in the studies of M. Liu et al. (2017) and Guo et al. (2017), was adopted for evaluating sulfate production in this study. In addition, in terms of oxidants, the obvious increase in the average concentration of $\mathrm{NO}_{2}$ (Fig. 5b) and the evident decrease in the average concentration of $\mathrm{O}_{3}$ (Fig. 5d) were observed with the deterioration of $\mathrm{PM}_{2.5}$ pollution. Furthermore, the average concentration of $\mathrm{H}_{2} \mathrm{O}_{2}$ was also found to be extremely high $(0.25 \mathrm{ppb})$ under the HP condition (Fig. 5c) and was above 1 order of magnitude higher than that $(0.01 \mathrm{ppb})$ assumed by Cheng et al. (2016), which probably resulted in the underestimation of the contribution of $\mathrm{H}_{2} \mathrm{O}_{2}$ to sulfate formation in the study of Cheng et al. (2016).

To further explore the contribution of $\mathrm{H}_{2} \mathrm{O}_{2}$ to the sulfate production rate under the HP condition, the parameters measured in this study (Table 2) and the same ap- 
(a)

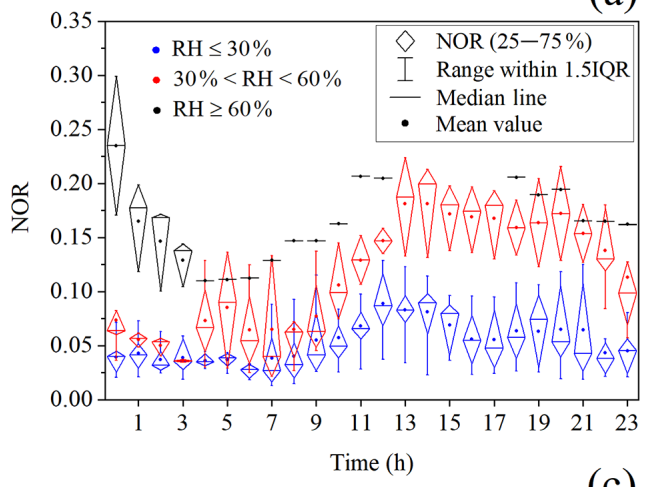

(c)

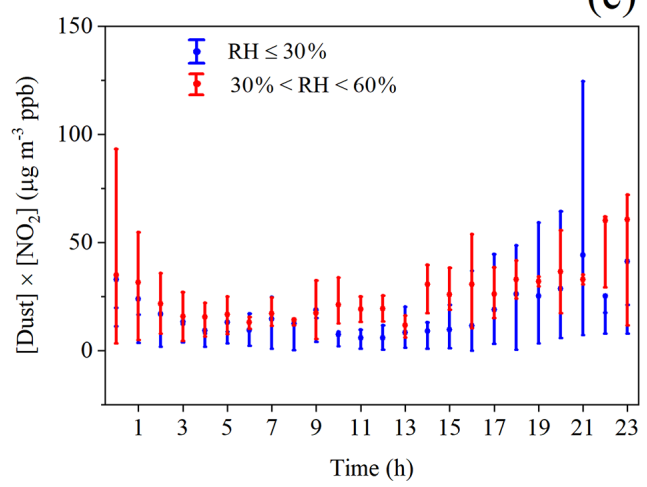

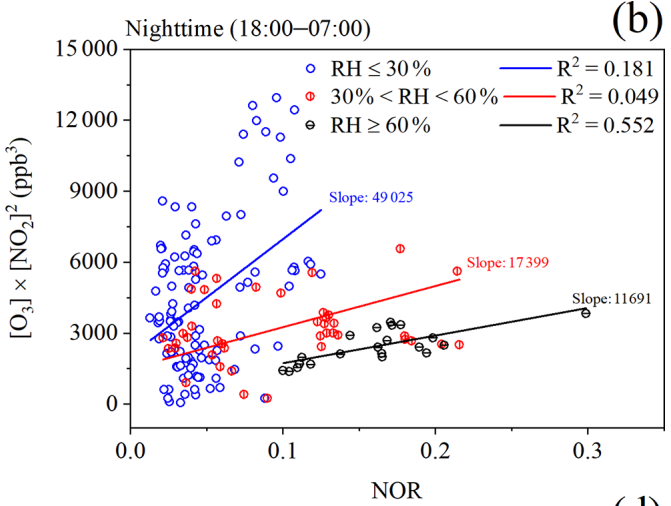

(d)

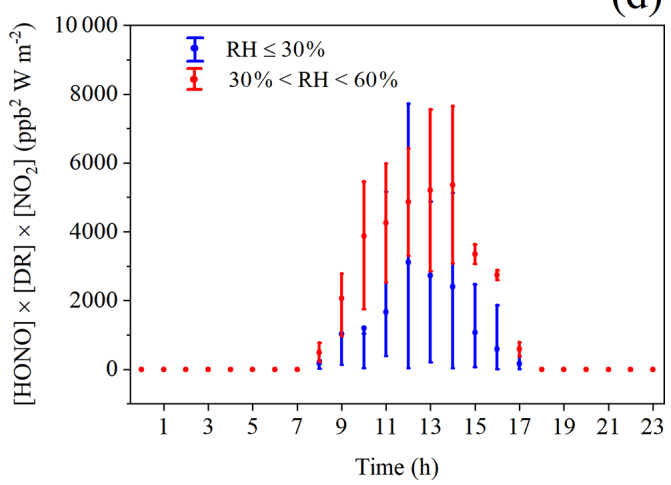

Figure 3. Daily variation in (a) NOR, (b) the correlation between NOR and $\left[\mathrm{NO}_{2}\right]^{2} \times\left[\mathrm{O}_{3}\right]$ in the nighttime (18:00-07:00 UTC+8), and (c, d) daily variations in $[$ Dust $]$ and $\left[\mathrm{NO}_{2}\right]$ and $[\mathrm{HONO}] \times[\mathrm{DR}] \times\left[\mathrm{NO}_{2}\right]$ under different atmospheric $\mathrm{RH}$ conditions during the sampling period.

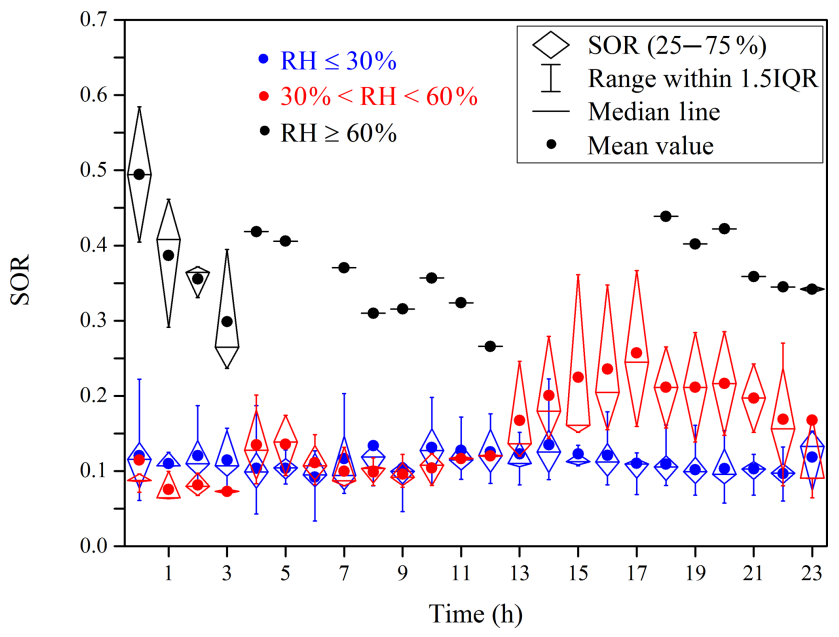

Figure 4. Daily variation in SOR under different atmospheric RH conditions during the sampling period.

proach that was adopted by Cheng et al. (2016) were used to calculate sulfate production. As shown in Fig. 6, the relationships between different aqueous oxidation pathways and aerosol $\mathrm{pH}$ in this study were found to be very similar to those of Cheng et al. (2016). However, the contribution of
$\mathrm{H}_{2} \mathrm{O}_{2}$ to sulfate production rate was about 17 times faster in this study (about $1.16 \mu \mathrm{g} \mathrm{m}^{-3} \mathrm{~h}^{-1}$ ) than in the study (about $6.95 \times 10^{-2} \mu \mathrm{g} \mathrm{m}^{-3} \mathrm{~h}^{-1}$ ) of Cheng et al. (2016), implying that the contribution of $\mathrm{H}_{2} \mathrm{O}_{2}$ to sulfate formation was largely neglected. Furthermore, considering the aerosol pH calculated under the HP condition during the sampling period, the oxidation pathway of $\mathrm{NO}_{2}$ might play an insignificant role in the sulfate production rate $\left(8.96 \times 10^{-2}-0.56 \mu \mathrm{g} \mathrm{m}^{-3} \mathrm{~h}^{-1}\right)$, and its importance proposed by the previous studies (1.74$10.85 \mathrm{\mu g} \mathrm{m}^{-3} \mathrm{~h}^{-1}$ ) is not necessarily expected.

\section{Conclusion}

Based on the comprehensive analysis of the pollution levels, the variation characteristics and the formation mechanisms of the key species in $\mathrm{PM}_{2.5}$ and the typical gaseous pollutants during the winter haze pollution periods in Beijing, three serious haze pollution cases were obtained during the sampling period, and SIA formations, especially nitrate and sulfate, were found to make an evident contribution to atmospheric $\mathrm{PM}_{2.5}$ under the relatively high $\mathrm{RH}$ condition. The significant correlation between $\left[\mathrm{NO}_{2}\right]^{2} \times\left[\mathrm{O}_{3}\right]$ and NOR at night under the $\mathrm{RH} \geq 60 \%$ condition indicated that the heterogeneous hydrolysis of $\mathrm{N}_{2} \mathrm{O}_{5}$ on wet aerosols 

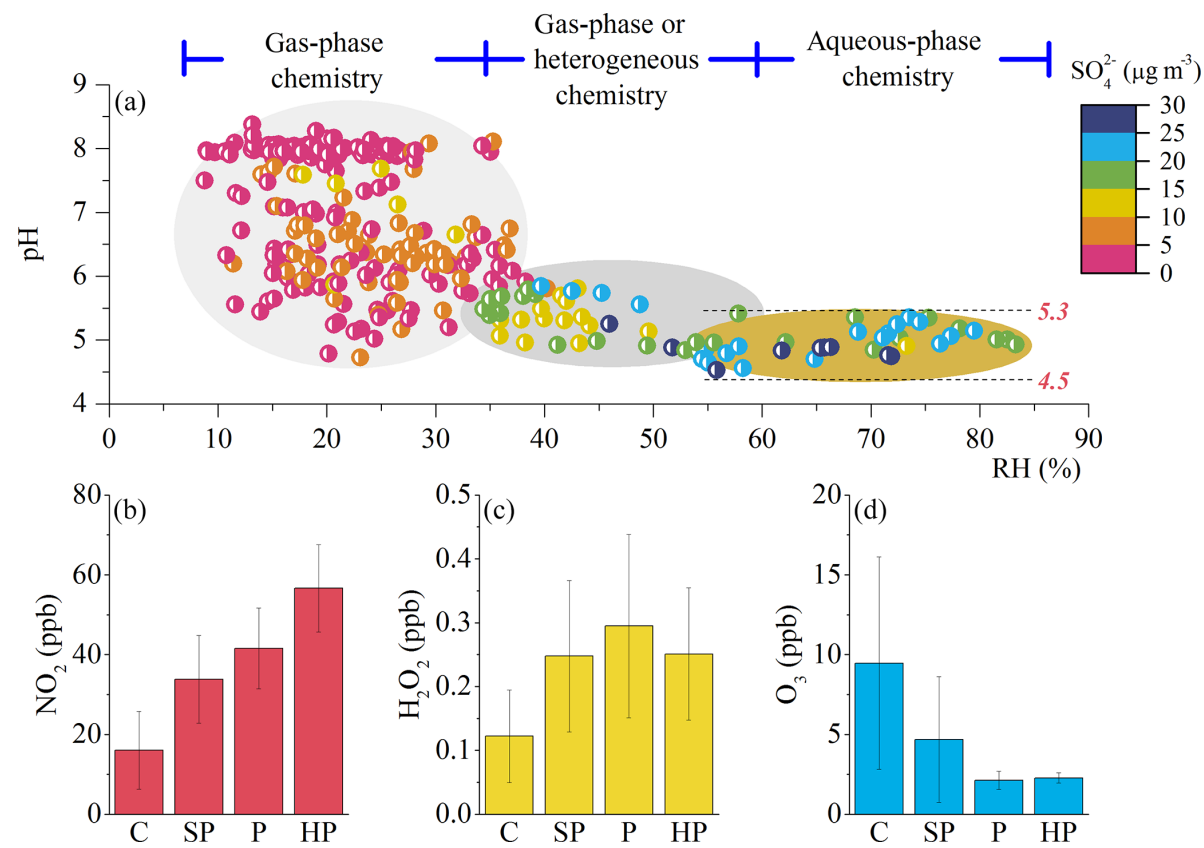

Figure 5. (a) The correlations among aerosol pH, atmospheric $\mathrm{RH}$ and atmospheric $\mathrm{SO}_{4}^{2-}$ and (b, c, d) the average concentrations of $\mathrm{NO}_{2}$, $\mathrm{H}_{2} \mathrm{O}_{2}$ and $\mathrm{O}_{3}$ under different pollution conditions - clean (C), $\mathrm{PM}_{2.5}<35 \mu \mathrm{g} \mathrm{m}^{-3}$; slightly polluted (SP), $35 \mu \mathrm{g} \mathrm{m}{ }^{-3}<\mathrm{PM}_{2.5}<75 \mu \mathrm{g} \mathrm{m}{ }^{-3}$; polluted (P), $75 \mu \mathrm{g} \mathrm{m}^{-3}<\mathrm{PM}_{2.5}<150 \mu \mathrm{g} \mathrm{m}^{-3}$; heavily polluted (HP), $\mathrm{PM}_{2.5}>150 \mu \mathrm{g} \mathrm{m}^{-3}$ - during the sampling period.
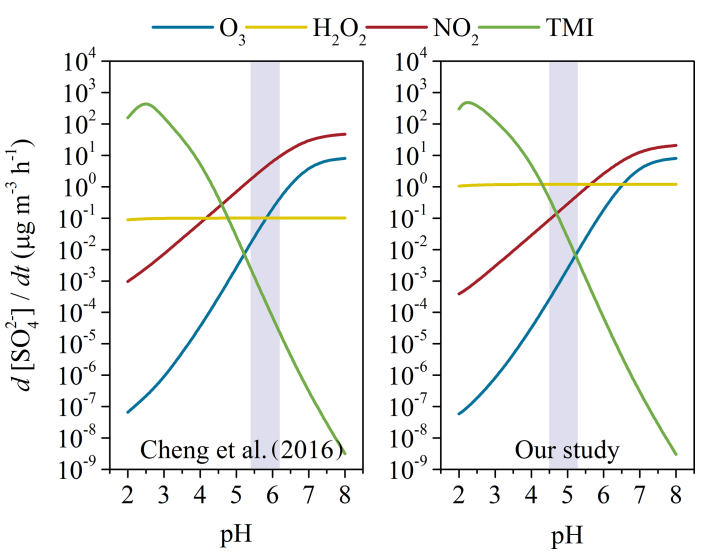

Figure 6. The comparison of aqueous-phase sulfate production by $\mathrm{SO}_{2}$ oxidation under different aerosol $\mathrm{pH}$ conditions between in the study of Cheng et al. (2016) and in this study.

was responsible for the nocturnal formation of nitrate under extremely high RH conditions. The more often coincident trend of $\mathrm{NOR}$ and $[\mathrm{HONO}] \times[\mathrm{DR}] \times\left[\mathrm{NO}_{2}\right]$ compared to its occurrence with [Dust $] \times\left[\mathrm{NO}_{2}\right]$ during the daytime under the $30 \%<\mathrm{RH}<60 \%$ condition suggested that the gasphase reaction of $\mathrm{NO}_{2}$ with $\mathrm{OH}$ played a key role in the diurnal formation of nitrate under moderate $\mathrm{RH}$ conditions. The extremely high mean values of SOR during the whole day under the $\mathrm{RH} \geq 60 \%$ condition could be explained by the dominant contribution of aqueous-phase reaction of $\mathrm{SO}_{2}$
Table 2. The comparisons of parameters of sulfate production rate calculations between in the study of Cheng et al. (2016) and in this work during the most polluted haze periods.

\begin{tabular}{lll}
\hline Parameters & This study & Cheng et al. (2016) \\
\hline $\mathrm{NO}_{2}$ & $57 \mathrm{ppb}$ & $66 \mathrm{ppb}$ \\
$\mathrm{H}_{2} \mathrm{O}_{2}$ & $0.25 \mathrm{ppb}$ & $0.01 \mathrm{ppb}$ \\
$\mathrm{O}_{3}$ & $2 \mathrm{ppb}$ & $1 \mathrm{ppb}$ \\
$\mathrm{SO}_{2}$ & $35 \mathrm{ppb}$ & $40 \mathrm{ppb}$ \\
$\mathrm{Fe}(\mathrm{III})^{*}$ & $18 \mathrm{ng} \mathrm{m}^{-3}$ & $18 \mathrm{ng} \mathrm{m}^{-3}$ \\
$\mathrm{Mn}(\mathrm{II})^{*}$ & $42 \mathrm{ng} \mathrm{m}^{-3}$ & $42 \mathrm{ng} \mathrm{m}^{-3}$ \\
ALWC & $146 \mu \mathrm{g} \mathrm{m}^{-3}$ & $300 \mu \mathrm{g} \mathrm{m}^{-3}$ \\
Aerosol droplet radius $(R)^{*}$ & $0.15 \mu \mathrm{m}$ & $0.15 \mu \mathrm{m}$ \\
Temperature & $270 \mathrm{~K}$ & $271 \mathrm{~K}$ \\
$\mathrm{pH}$ & $4.5-5.3$ & $5.4-6.2$ \\
\hline
\end{tabular}

* Both of the concentrations of $\mathrm{Fe}(\mathrm{III})$ and $\mathrm{Mn}$ (II) and aerosol droplet radius were not measured in this study and were derived from Cheng et al. (2016).

to atmospheric sulfate formation during the severe pollution episodes. According to the parameters measured in this study and the same approach that was adopted by Cheng et al. (2016), the oxidation pathway of $\mathrm{H}_{2} \mathrm{O}_{2}$ rather than $\mathrm{NO}_{2}$ was found to contribute greatly to atmospheric sulfate formation.

Our results revealed that the heavy pollution events in winter usually occurred with high concentration levels of pollutants and oxidants as well as high liquid water content of moderately acidic aerosols in the NCP. Thus, emission controls of $\mathrm{NO}_{x}, \mathrm{SO}_{2}$ and VOCs especially under the extremely 
high RH conditions are expected to largely reduce the pollution levels of nitrate and sulfate in northern China and even in other pollution regions of China.

Data availability. Data are available from the corresponding author upon request (yjmu@ @rcees.ac.cn).

Supplement. The supplement related to this article is available online at: https://doi.org/10.5194/acp-20-4153-2020-supplement.

Author contributions. YM designed the experiments. PL carried out the experiments and prepared the paper. CY and CX carried out the experiments. $\mathrm{CZ}$ was involved in part of the work. XS provided the meteorological data and trace gases in Beijing.

Competing interests. The authors declare that they have no conflict of interest.

Special issue statement. This article is part of the special issue "Multiphase chemistry of secondary aerosol formation under severe haze". It is not associated with a conference.

Financial support. This research has been supported by the National research program for Key issues in air pollution control (grant nos. DQGG0103, DQGG0209 and DQGG0206), the National Natural Science Foundation of China (grant nos. 91544211, 4127805, 41575121 and 21707151), the National Key Research and Development Program of China (grant nos. 2016YFC0202200, 2017YFC0209703 and 2017YFF0108301) and the Key Laboratory of Atmospheric Chemistry, China Meteorological Administration (grant no. 2018B03).

Review statement. This paper was edited by Veli-Matti Kerminen and reviewed by two anonymous referees.

\section{References}

Bei, N., Wu, J., Elser, M., Feng, T., Cao, J., El-Haddad, I., Li, X., Huang, R., Li, Z., Long, X., Xing, L., Zhao, S., Tie, X., Prévôt, A. S. H., and Li, G.: Impacts of meteorological uncertainties on the haze formation in Beijing-Tianjin-Hebei (BTH) during wintertime: a case study, Atmos. Chem. Phys., 17, 14579-14591, https://doi.org/10.5194/acp-17-14579-2017, 2017.

Bougiatioti, A., Nikolaou, P., Stavroulas, I., Kouvarakis, G., Weber, R., Nenes, A., Kanakidou, M., and Mihalopoulos, N.: Particle water and $\mathrm{pH}$ in the eastern Mediterranean: source variability and implications for nutrient availability, Atmos. Chem. Phys., 16, 4579-4591, https://doi.org/10.5194/acp-16-4579-2016, 2016.
Chan, C. K. and Yao, X.: Air pollution in mega cities in China, Atmos. Environ., 42, 1-42, https://doi.org/10.1016/j.atmosenv.2007.09.003, 2008.

Chen, L. H., Sun, Y. Y., Wu, X. C., Zhang, Y. X., Zheng, C. H., Gao, X., and Cen, K.: Unit-based emission inventory and uncertainty assessment of coal-fired power plants, Atmos. Environ., 99, 527535, https://doi.org/10.1016/j.atmosenv.2014.10.023, 2014.

Cheng, Y., Zheng, G., Wei, C., Mu, Q., Zheng, B., Wang, Z., Gao, M., Zhang, Q., He, K., Carmichael, G., Pöschl, U., and Su, H.: Reactive nitrogen chemistry in aerosol water as a source of sulfate during haze events in China, Sci. Adv., 2, 1-11, https://doi.org/10.1126/sciadv.1601530, 2016.

Clifton, C. L., Altstein, N., and Huie, R. E.: Rate-constant for the reaction of $\mathrm{NO}_{2}$ with sulfur(IV) over the $\mathrm{pH}$ range 5.3-13, Environ. Sci. Technol., 22, 586-589, https://doi.org/10.1021/es00170a018, 1988.

Dai, Q., Bi, X., Song, W., Li, T., Liu, B., Ding, J., Xu, J., Song, C., Yang, N., Schulze, B. C., Zhang, Y., Feng, Y., and Hopke, P. K.: Residential coal combustion as a source of primary sulfate in Xi'an, China, Atmos. Environ., 196, 66-76, https://doi.org/10.1016/j.atmosenv.2018.10.002, 2019.

Ding, J., Zhao, P., Su, J., Dong, Q., Du, X., and Zhang, Y.: Aerosol $\mathrm{pH}$ and its driving factors in Beijing, Atmos. Chem. Phys., 19, 7939-7954, https://doi.org/10.5194/acp-19-7939-2019, 2019.

Du, Q., Zhang, C., Mu, Y., Cheng, Y., Zhang, Y., Liu, C., Song, M., Tian, D., Liu, P., Liu, J., Xue, C., and Ye, C.: An important missing source of atmospheric carbonyl sulfide: Domestic coal combustion, Geophys. Res. Lett., 43, 8720-8727, https://doi.org/10.1002/2016gl070075, 2016.

Fountoukis, C. and Nenes, A.: ISORROPIA II: a computationally efficient thermodynamic equilibrium model for $\mathrm{K}^{+}$. $\mathrm{Ca}^{2+}-\mathrm{Mg}^{2+}-\mathrm{NH}_{4}^{+}-\mathrm{Na}^{+}-\mathrm{SO}_{4}^{2-}-\mathrm{NO}_{3}^{-}-\mathrm{Cl}^{-}-\mathrm{H}_{2} \mathrm{O}$ aerosols, Atmos. Chem. Phys., 7, 4639-4659, https://doi.org/10.5194/acp-74639-2007, 2007.

Ge, X., He, Y., Sun, Y., Xu, J., Wang, J., Shen, Y., and Chen, M.: Characteristics and Formation Mechanisms of Fine Particulate Nitrate in Typical Urban Areas in China, Atmosphere, 8, 62, https://doi.org/10.3390/atmos8030062, 2017.

Graedel, T. E. and Weschler, C. J.: Chemistry within aqueous atmospheric aerosols and raindrops, Rev. Geophys., 19, 505-539, https://doi.org/10.1029/RG019i004p00505, 1981.

Guo, H., Xu, L., Bougiatioti, A., Cerully, K. M., Capps, S. L., Hite Jr., J. R., Carlton, A. G., Lee, S.-H., Bergin, M. H., Ng, N. L., Nenes, A., and Weber, R. J.: Fine-particle water and $\mathrm{pH}$ in the southeastern United States, Atmos. Chem. Phys., 15, 5211-5228, https://doi.org/10.5194/acp-15-5211-2015, 2015.

Guo, H., Weber, R. J., and Nenes, A.: High levels of ammonia do not raise fine particle $\mathrm{pH}$ sufficiently to yield nitrogen oxide-dominated sulfate production, Sci. Rep.-UK, 7, 12109, https://doi.org/10.1038/s41598-017-11704-0, 2017.

Guo, S., Hu, M., Zamora, M. L., Peng, J., Shang, D., Zheng, J., Du, Z., Wu, Z., Shao, M., Zeng, L., Molina, M. J., and Zhang, R.: Elucidating severe urban haze formation in China, P. Natl. Acad. Sci. USA, 111, 17373-17378, https://doi.org/10.1073/pnas.1419604111, 2014.

He, H., Wang, Y., Ma, Q., Ma, J., Chu, B., Ji, D., Tang, G., Liu, C., Zhang, H., and Hao, J.: Mineral dust and $\mathrm{NO}_{x}$ promote the conversion of $\mathrm{SO}_{2}$ to sulfate in heavy pollution days, Sci. Rep.UK, 4, 1-5, https://doi.org/10.1038/srep04172, 2014. 
He, P., Xie, Z., Chi, X., Yu, X., Fan, S., Kang, H., Liu, C., and Zhan, H.: Atmospheric $\Delta^{17} O\left(\mathrm{NO}_{3}^{-}\right)$reveals nocturnal chemistry dominates nitrate production in Beijing haze, Atmos. Chem. Phys., 18, 14465-14476, https://doi.org/10.5194/acp-18-144652018, 2018.

Hennigan, C. J., Izumi, J., Sullivan, A. P., Weber, R. J., and Nenes, A.: A critical evaluation of proxy methods used to estimate the acidity of atmospheric particles, Atmos. Chem. Phys., 15, 27752790, https://doi.org/10.5194/acp-15-2775-2015, 2015.

Huang, R. J., Zhang, Y., Bozzetti, C., Ho, K. F., Cao, J. J., Han, Y., Daellenbach, K. R., Slowik, J. G., Platt, S. M., Canonaco, F., Zotter, P., Wolf, R., Pieber, S. M., Bruns, E. A., Crippa, M., Ciarelli, G., Piazzalunga, A., Schwikowski, M., Abbaszade, G., SchnelleKreis, J., Zimmermann, R., An, Z., Szidat, S., Baltensperger, U., El Haddad, I., and Prevot, A. S.: High secondary aerosol contribution to particulate pollution during haze events in China, Nature, 514, 218-222, https://doi.org/10.1038/nature13774, 2014.

Ibusuki, T. and Takeuchi, K.: Sulfur-dioxide oxidation by oxygen catalyzed by mixtures of manganese(II) and iron(III) in aqueoussolutions at environmental reaction conditions, Atmos. Environ., 21, 1555-1560, https://doi.org/10.1016/0004-6981(87)90317-9, 1987.

Li, G., Bei, N., Cao, J., Huang, R., Wu, J., Feng, T., Wang, Y., Liu, S., Zhang, Q., Tie, X., and Molina, L. T.: A possible pathway for rapid growth of sulfate during haze days in China, Atmos. Chem. Phys., 17, 3301-3316, https://doi.org/10.5194/acp17-3301-2017, 2017.

Li, J., Liao, H., Hu, J., and Li, N.: Severe particulate pollution days in China during 2013-2018 and the associated typical weather patterns in Beijing-Tianjin-Hebei and the Yangtze River Delta regions, Environ. Pollut., 248, 74-81, https://doi.org/10.1016/j.envpol.2019.01.124, 2019.

Li, L., Hoffmann, M. R., and Colussi, A. J.: Role of nitrogen dioxide in the production of sulfate during Chinese haze-aerosol episodes, Environ. Sci. Technol., 52, 2686-2693, https://doi.org/10.1021/acs.est.7b05222, 2018.

Li, Q., Li, X., Jiang, J., Duan, L., Ge, S., Zhang, Q., Deng, J., Wang, S., and Hao, J.: Semi-coke briquettes: towards reducing emissions of primary $\mathrm{PM}_{2.5}$, particulate carbon, and carbon monoxide from household coal combustion in China, Sci. Rep.-UK, 6, 1-10, https://doi.org/10.1038/srep19306, 2016.

Liu, M., Song, Y., Zhou, T., Xu, Z., Yan, C., Zheng, M., Wu, Z., $\mathrm{Hu}, \mathrm{M} ., \mathrm{Wu}, \mathrm{Y}$, and $\mathrm{Zhu}$, T.: Fine particle $\mathrm{pH}$ during severe haze episodes in northern China, Geophys. Res. Lett., 44, 1-9, https://doi.org/10.1002/2017GL073210, 2017.

Liu, P., Zhang, C., Mu, Y., Liu, C., Xue, C., Ye, C., Liu, J., Zhang, Y., and Zhang, H.: The possible contribution of the periodic emissions from farmers' activities in the North China Plain to atmospheric water-soluble ions in Beijing, Atmos. Chem. Phys., 16, 10097-10109, https://doi.org/10.5194/acp-16-100972016, 2016.

Liu, P., Zhang, C., Xue, C., Mu, Y., Liu, J., Zhang, Y., Tian, D., Ye, C., Zhang, H., and Guan, J.: The contribution of residential coal combustion to atmospheric $\mathrm{PM}_{2.5}$ in northern China during winter, Atmos. Chem. Phys., 17, 11503-11520, https://doi.org/10.5194/acp-17-11503-2017, 2017.

Ma, Q., Wang, T., Liu, C., He, H., Wang, Z., Wang, W., and Liang, Y.: $\mathrm{SO}_{2}$ Initiates the efficient conversion of $\mathrm{NO}_{2}$ to
HONO on MgO Surface, Environ. Sci. Technol., 51, 3767-3775, https://doi.org/10.1021/acs.est.6b05724, 2017.

Meng, Z. Y., Lin, W. L., Jiang, X. M., Yan, P., Wang, Y., Zhang, Y. M., Jia, X. F., and Yu, X. L.: Characteristics of atmospheric ammonia over Beijing, China, Atmos. Chem. Phys., 11, 61396151, https://doi.org/10.5194/acp-11-6139-2011, 2011.

Murphy, J. G., Gregoire, P. K., Tevlin, A. G., Wentworth, G. R., Ellis, R. A., Markovic, M. Z., and VandenBoer, T. C.: Observational constraints on particle acidity using measurements and modelling of particles and gases, Faraday Discuss., 200, 379395, https://doi.org/10.1039/c7fd00086c, 2017.

Nie, W., Ding, A., Wang, T., Kerminen, V. M., George, C., Xue, L., Wang, W., Zhang, Q., Petaja, T., Qi, X., Gao, X., Wang, X., Yang, X., Fu, C., and Kulmala, M.: Polluted dust promotes new particle formation and growth, Sci. Rep.-UK, 4, 1-6, https://doi.org/10.1038/srep06634, 2014.

Pathak, R. K., Louie, P. K. K., and Chan, C. K.: Characteristics of aerosol acidity in Hong kong, Atmos. Environ., 38, 2965-2974, https://doi.org/10.1016/j.atmosenv.2004.02.044, 2004.

Ponczek, M., Hayeck, N., Emmelin, C., and George, C.: Heterogeneous photochemistry of dicarboxylic acids on mineral dust, Atmos. Environ., 212, 262-271, https://doi.org/10.1016/j.atmosenv.2019.05.032, 2019.

Quan, J., Tie, X., Zhang, Q., Liu, Q., Li, X., Gao, Y., and Zhao, D.: Characteristics of heavy aerosol pollution during the 20122013 winter in Beijing, China, Atmos. Environ., 88, 83-89, https://doi.org/10.1016/j.atmosenv.2014.01.058, 2014.

Ravishankara, A.: Heterogeneous and multiphase chemistry in the troposphere, Science, 276, 1058-1065, 1997.

Seinfeld, J. H. and Pandis, S. N.: Atmospheric Chemistry and Physics, from Air Pollution to Climate Change, John Wiley and Sons, Inc., 429-44, 2006.

Shao, J., Chen, Q., Wang, Y., Lu, X., He, P., Sun, Y., Shah, V., Martin, R. V., Philip, S., Song, S., Zhao, Y., Xie, Z., Zhang, L., and Alexander, B.: Heterogeneous sulfate aerosol formation mechanisms during wintertime Chinese haze events: air quality model assessment using observations of sulfate oxygen isotopes in Beijing, Atmos. Chem. Phys., 19, 6107-6123, https://doi.org/10.5194/acp-19-6107-2019, 2019.

Shi, G., Xu, J., Peng, X., Xiao, Z., Chen, K., Tian, Y., Guan, X., Feng, Y., Yu, H., Nenes, A., and Russell, A. G.: pH of aerosols in a polluted atmosphere: source contributions to highly acidic aerosol, Environ. Sci. Technol., 51, 4289-4296, https://doi.org/10.1021/acs.est.6b05736, 2017.

Sun, Y., Wang, Z., Fu, P., Jiang, Q., Yang, T., Li, J., and Ge, X.: The impact of relative humidity on aerosol composition and evolution processes during wintertime in Beijing, China, Atmos. Environ., 77, 927-934, https://doi.org/10.1016/j.atmosenv.2013.06.019, 2013.

Tang, M., Huang, X., Lu, K., Ge, M., Li, Y., Cheng, P., Zhu, T., Ding, A., Zhang, Y., Gligorovski, S., Song, W., Ding, X., Bi, X., and Wang, X.: Heterogeneous reactions of mineral dust aerosol: implications for tropospheric oxidation capacity, Atmos. Chem. Phys., 17, 11727-11777, https://doi.org/10.5194/acp-17-117272017, 2017.

Tham, Y. J., Wang, Z., Li, Q., Wang, W., Wang, X., Lu, K., Ma, N., Yan, C., Kecorius, S., Wiedensohler, A., Zhang, Y., and Wang, T.: Heterogeneous $\mathrm{N}_{2} \mathrm{O}_{5}$ uptake coefficient and production yield of $\mathrm{ClNO}_{2}$ in polluted northern China: roles of aerosol water con- 
tent and chemical composition, Atmos. Chem. Phys., 18, 1315513171, https://doi.org/10.5194/acp-18-13155-2018, 2018.

Tong, S. R., Hou, S. Q., Zhang, Y., Chu, B. W., Liu, Y. C., He, H., Zhao, P. S., and Ge, M. F.: Exploring the nitrous acid (HONO) formation mechanism in winter Beijing: direct emissions and heterogeneous production in urban and suburban areas, Faraday Discuss., 189, 213-230, https://doi.org/10.1039/c5fd00163c, 2016.

Wang, G., Zhang, R., Gomez, M. E., Yang, L., Levy Zamora, M., Hu, M., Lin, Y., Peng, J., Guo, S., Meng, J., Li, J., Cheng, C., Hu, T., Ren, Y., Wang, Y., Gao, J., Cao, J., An, Z., Zhou, W., Li, G., Wang, J., Tian, P., Marrero-Ortiz, W., Secrest, J., Du, Z., Zheng, J., Shang, D., Zeng, L., Shao, M., Wang, W., Huang, Y., Wang, Y., Zhu, Y., Li, Y., Hu, J., Pan, B., Cai, L., Cheng, Y., Ji, Y., Zhang, F., Rosenfeld, D., Liss, P. S., Duce, R. A., Kolb, C. E., and Molina, M. J.: Persistent sulfate formation from London Fog to Chinese haze, P. Natl. Acad. Sci. USA, 113, 13630-13635, 2016.

Wang, G., Zhang, F., Peng, J., Duan, L., Ji, Y., Marrero-Ortiz, W., Wang, J., Li, J., Wu, C., Cao, C., Wang, Y., Zheng, J., Secrest, J., Li, Y., Wang, Y., Li, H., Li, N., and Zhang, R.: Particle acidity and sulfate production during severe haze events in China cannot be reliably inferred by assuming a mixture of inorganic salts, Atmos. Chem. Phys., 18, 10123-10132, https://doi.org/10.5194/acp-18-10123-2018, 2018.

Wang, H., Lu, K., Chen, X., Zhu, Q., Wu, Z., Wu, Y., and Sun, K.: Fast particulate nitrate formation via $\mathrm{N}_{2} \mathrm{O}_{5}$ uptake aloft in winter in Beijing, Atmos. Chem. Phys., 18, 10483-10495, https://doi.org/10.5194/acp-18-10483-2018, 2018 a.

Wang, H., Lu, K., Guo, S., Wu, Z., Shang, D., Tan, Z., Wang, Y., Le Breton, M., Lou, S., Tang, M., Wu, Y., Zhu, W., Zheng, J., Zeng, L., Hallquist, M., Hu, M., and Zhang, Y.: Efficient $\mathrm{N}_{2} \mathrm{O}_{5}$ uptake and $\mathrm{NO}_{3}$ oxidation in the outflow of urban Beijing, Atmos. Chem. Phys., 18, 9705-9721, https://doi.org/10.5194/acp18-9705-2018, 2018 b.

Wang, J., Zhang, X., Guo, J., Wang, Z., and Zhang, M.: Observation of nitrous acid (HONO) in Beijing, China: Seasonal variation, nocturnal formation and daytime budget, Sci. Total Environ., 587-588, 350-359, https://doi.org/10.1016/j.scitotenv.2017.02.159, 2017.

Wang, Y., Yao, L., Wang, L., Liu, Z., Ji, D., Tang, G., Zhang, J., Sun, Y., Hu, B., and Xin, J.: Mechanism for the formation of the January 2013 heavy haze pollution episode over central and eastern China, Sci. China Earth Sci., 57, 14-25, https://doi.org/10.1007/s11430-013-4773-4, 2013.

Weber, R. J., Guo, H., Russell, A. G., and Nenes, A.: High aerosol acidity despite declining atmospheric sulfate concentrations over the past 15 years, Nat. Geosci., 9, 282-285, https://doi.org/10.1038/ngeo2665, 2016.

Wu, J., Bei, N., Hu, B., Liu, S., Zhou, M., Wang, Q., Li, X., Liu, L., Feng, T., Liu, Z., Wang, Y., Cao, J., Tie, X., Wang, J., Molina, L. T., and Li, G.: Is water vapor a key player of the wintertime haze in North China Plain?, Atmos. Chem. Phys., 19, 87218739, https://doi.org/10.5194/acp-19-8721-2019, 2019.

Xu, L., Duan, F., He, K., Ma, Y., Zhu, L., Zheng, Y., Huang, T., Kimoto, T., Ma, T., Li, H., Ye, S., Yang, S., Sun, Z., and Xu, B.: Characteristics of the secondary water-soluble ions in a typical autumn haze in Beijing, Environ. Pollut., 227, 296-305, https://doi.org/10.1016/j.envpol.2017.04.076, 2017.
Xu, W. Y., Zhao, C. S., Ran, L., Deng, Z. Z., Liu, P. F., Ma, N., Lin, W. L., Xu, X. B., Yan, P., He, X., Yu, J., Liang, W. D., and Chen, L. L.: Characteristics of pollutants and their correlation to meteorological conditions at a suburban site in the North China Plain, Atmos. Chem. Phys., 11, 4353-4369, https://doi.org/10.5194/acp-11-4353-2011, 2011.

Xue, C., Ye, C., Ma, Z., Liu, P., Zhang, Y., Zhang, C., Tang, K., Zhang, W., Zhao, X., Wang, Y., Song, M., Liu, J., Duan, J., Qin, M., Tong, S., Ge, M., and Mu, Y.: Development of stripping coil-ion chromatograph method and intercomparison with CEAS and LOPAP to measure atmospheric HONO, Sci. Total Environ., 646, 187-195, https://doi.org/10.1016/j.scitotenv.2018.07.244, 2019a.

Xue, C., Ye, C., Zhang, Y., Ma, Z., Liu, P., Zhang, C., Zhao, X., Liu, J., and Mu, Y.: Development and application of a twin open-top chambers method to measure soil HONO emission in the North China Plain, Sci. Total Environ., 659, 621-631, https://doi.org/10.1016/j.scitotenv.2018.12.245, 2019 b.

Xue, J., Yuan, Z., Griffith, S. M., Yu, X., Lau, A. K., and Yu, J. Z.: Sulfate Formation Enhanced by a Cocktail of High $\mathrm{NO}_{x}, \mathrm{SO}_{2}$, Particulate Matter, and Droplet $\mathrm{pH}$ during HazeFog Events in Megacities in China: An Observation-Based Modeling Investigation, Environ. Sci. Technol., 50, 7325-7334, https://doi.org/10.1021/acs.est.6b00768, 2016.

Yang, T., Sun, Y., Zhang, W., Wang, Z., Liu, X., Fu, P., and Wang, X.: Evolutionary processes and sources of high-nitrate haze episodes over Beijing, Spring, J. Environ. Sci., 54, 142-151, https://doi.org/10.1016/j.jes.2016.04.024, 2017.

Yang, Y. R., Liu, X. G., Qu, Y., An, J. L., Jiang, R., Zhang, Y. H., Sun, Y. L., Wu, Z. J., Zhang, F., Xu, W. Q., and Ma, Q. X.: Characteristics and formation mechanism of continuous hazes in China: a case study during the autumn of 2014 in the North China Plain, Atmos. Chem. Phys., 15, 8165-8178, https://doi.org/10.5194/acp-15-8165-2015, 2015.

Ye, C., Liu, P., Ma, Z., Xue, C., Zhang, C., Zhang, Y., Liu, J., Liu, C., Sun, X., and $\mathrm{Mu}$, Y.: High $\mathrm{H}_{2} \mathrm{O}_{2}$ Concentrations Observed during Haze Periods during the Winter in Beijing: Importance of $\mathrm{H}_{2} \mathrm{O}_{2}$ Oxidation in Sulfate Formation, Environ. Sci. Tech. Let., 5, 757-763, https://doi.org/10.1021/acs.estlett.8b00579, 2018.

Zhang, H., Chen, S., Zhong, J., Zhang, S., Zhang, Y., Zhang, X., Li, Z., and Zeng, X. C.: Formation of aqueousphase sulfate during the haze period in China: Kinetics and atmospheric implications, Atmos. Environ., 177, 93-99, https://doi.org/10.1016/j.atmosenv.2018.01.017, 2018.

Zhang, Q., He, K. B., and Huo, H.: Cleaning China's air, Nature, 484, 161-162, 2012.

Zhang, R., Wang, G., Guo, S., Zamora, M. L., Ying, Q., Lin, Y., Wang, W., Hu, M., and Wang, Y.: Formation of urban fine particulate matter, Chem. Rev., 115, 3803-3855, https://doi.org/10.1021/acs.chemrev.5b00067, 2015.

Zhao, M., Wang, S., Tan, J., Hua, Y., Wu, D., and Hao, J.: Variation of Urban Atmospheric Ammonia Pollution and its Relation with $\mathrm{PM}_{2.5}$ Chemical Property in Winter of Beijing, China, Aerosol Air Qual. Res., 16, 1390-1402, https://doi.org/10.4209/aaqr.2015.12.0699, 2016.

Zheng, B., Zhang, Q., Zhang, Y., He, K. B., Wang, K., Zheng, G. J., Duan, F. K., Ma, Y. L., and Kimoto, T.: Heterogeneous chemistry: a mechanism missing in current models to explain secondary inorganic aerosol formation during the January 2013 haze 
episode in North China, Atmos. Chem. Phys., 15, 2031-2049, https://doi.org/10.5194/acp-15-2031-2015, 2015a.

Zheng, G. J., Duan, F. K., Su, H., Ma, Y. L., Cheng, Y., Zheng, B., Zhang, Q., Huang, T., Kimoto, T., Chang, D., Pöschl, U., Cheng, Y. F., and He, K. B.: Exploring the severe winter haze in Beijing: the impact of synoptic weather, regional transport and heterogeneous reactions, Atmos. Chem. Phys., 15, 2969-2983, https://doi.org/10.5194/acp-15-2969-2015, 2015 b.
Zhong, J., Zhang, X., Wang, Y., Wang, J., Shen, X., Zhang, H., Wang, T., Xie, Z., Liu, C., Zhang, H., Zhao, T., Sun, J., Fan, S., Gao, Z., Li, Y., and Wang, L.: The two-way feedback mechanism between unfavorable meteorological conditions and cumulative aerosol pollution in various haze regions of China, Atmos. Chem. Phys., 19, 3287-3306, https://doi.org/10.5194/acp19-3287-2019, 2019. 